\title{
IMF RECOMMENDATIONS ON THE OBSERVANCE OF STANDARDS AND CODES OF ACCOUNTING AND AUDITING BASED ON REPORT - REPUBLIC SLOVENIA CASE
}

\author{
Božidar Jager \\ Law Faculty of University of Maribor, Maribor Slovenia
}

\author{
Key words: \\ Corporate Financial Reports, \\ International Financial Reporting \\ Standards, \\ International Auditing Standards, \\ System Risk, \\ Comparison.
}

\section{SUBJECT, DEFINITION AND OBJECT}

\subsection{Auditing and auditing object}

A term "revision" originates from Latin world »revidere«, what in translation means "once again to take view into the last corrigendum" and in accordance with it means additional review and verification of different processes and components. The English world "audit" becomes from Latin world "audire", what means "to be heard". The same original meaning of world "auditor" is the listener. The world is used long time ago, when the financial reports were approved after they were publicly read to audience by competent accountants. «1

Auditing is broadly defined as a "systematic procedure of neutral acquisition and evaluation proofs connected with official statements of business activities and events to establish the level of harmonization of those public statements according to accepted principles and reporting of results the interested party $\aleph^{2}$ In the usual sense of the word the auditing can be classified regarding to purpose of their activities to:

- Auditing financial reports,

- Auditing accordance to rules, and

- Operational auditing.

With regard to connection between the audit activity performers we determine external and internal auditing as well as public auditing. It is executed by public servants. For example the officials of state agency verifies accordance to regulations, administration of Taxes deals with taxation and superior auditing institution examines programs, activities and execution of different state administration sectors. The main stress of public auditing presented in papers delivered at the symposium conference is public internal auditing.

\subsection{Conception of audit, internal audit, budget and budget execution auditing}

Determination according to the opinion of author Kranjčević ${ }^{3}$ the term audit originates in Latin word "revisum «, what means examined or looked over subsequently for investigation and estimation. Between different conceptions of the term audit

1 Whittington, O.R. at all, Principles of Auditing, IRWIN, Homewood 1992, str. 7

2 Taylor, Donald, Revidiranje; zasnove in postopki, Slovenski inštitut za revizijo, Ljubljana, 1996,p. 32

3 Franjo Kranjčević, Revizija i kontrola, Informator Zagreb, 1972, str. 9 the most definitions deals with accounting auditing. This is understandable because this term was the first established. In the year 1923 Grasgruen »defines auditing as general and additional examination of operations by reviewing the company books like the general ledger by employment the special external authorized persons «. ${ }^{4}$

The term internal auditing is determined in technical literature. »Internal auditing presents by external audit a couple of critical and subsequent verification former past events in organization that is with a distinction performed by competent internal body of organization that is examined.".$^{5}$

In a Book „Kontrola i revizija poslovanja“the author dr. Kranjčević already in a year 1966 presented the reasons for establishing the internal audit body. It depends of an enterprise grow, interruptions in company, unreliable internal control and insufficiency of external audit.

Development of internal auditing was at the beginning under a strong USA American influence of activity known as Internal Audit, later in Germany, known under term Interne Revision or Pruefung. Educational Committee of the Institute of Internal Auditors defined internal auditing as "an activity in helping to improve business and toachieve maximalsuccess ${ }^{6}$.

After Slovenian independence The Company Law (ZGD) for economic enterpriseswas accepted. So the demand for auditing financial reports of companies got the legal base and auditing activities in state were established. Auditing activities were regulated by Auditing Law. In fact there were lacks of auditing expert workers in state so the different activities for overcoming sufficiency were undertaken. The Slovenian Association of Accounting and Financial Laborers were included in that activity together with Austrian experts framed with the Academy of economic auditors. ${ }^{7}$ They organized the eleven weekend's intensive colloquium for selected participants which finished it with an adequate attestation.

Due to Auditing Act The Slovenian Institute of auditors (SIR) was established. It is the official subject to take care for law provisions, education and professional association on auditing field. It also certificates The Institute's educational courses and gives attestations and marks for the participation on educational conferences. SIR takes care for professional development by

4 Grasgruen, A: Revisionen, Berlin, 1923, str. 289, ,page 9

5 Remark at 4 , str. 11

6 The Field of Internal Auditing, The Institute of Internal Auditors, New York, 1953, Op. pod 1. Page 13

7 Akademie der Wirtschaftstreuhaender, 1121 Wien, Schoenbrunner str. $222-228$ 
publication translated works like ISA standards ${ }^{8}$ and INTOSAI, auditing standards ${ }^{9}$.

Under the Slovenian Local self- management law (ZLS), the local communities got duties to execute all tasks relating matters of local community. The local authorities are authorized by Law of community financing (ZFO) for budget preparation, budget execution and financial reporting to Council of local municipality and to Slovenian Court of account and to Slovenian Ministry of Finance. At the beginning the state authorities introduced state auditing for supervising public expenses. The Slovenian court of accounts was established in a year 1995 as an external supervising agency and control body for budget of state and all public sector. ${ }^{10}$

There are four groups of Budget users:

- Direct users of state and local budget (state and municipalities),

- Indirect users: Public enterprises established by state or local authorities.

- Agency for Pension and disable workers fund,

- Other public sector entities:

Public enterprises.

Community entities,

Other public entities under state or municipality influence for to manage the business.

The Law of community financing defines that the budget is on the grounds of cash flow basis.Incomes and outcomes are the matter of evidence after they are performed.

There are three contents of State and local budget:

a. Incomes and outcomes Balance,

b. The capital demands and liabilities account,

c. The finance investment account

The budget principles for public finance in Republic of Slovenia are as follows:

- Principle of macroeconomics stability anticipates the deficit should be low as possible.

- Principle of thriftiness. For reasons of economy budget resources are used just for financing state and municipalities duties based on law.

- Principle of efficiency and economy is demand that available means of finance ensures maximal result.

- Principle of analyzing cost and benefit. Measures with huge finance consequences should be the matter of argumentation.

- Principle of budget equilibration. The budget incomes and outcomes should be balanced.

- Principle of Integrity. In a state and municipality budget should be attested all incomes and outcomes.

- Principle of gross budget. Incomes and outcomes should be attested as a gross value without mutual interaction or settlement.

- Principle of integral covering or the principle of unbound connection between incomes and outcomes. Taxes should be designed for budget general finance purposes without prior intention. All collected money should be gathered and then distributed.

- Principle of one-year budget. All budget incomes and outcomes should cover 12 months.

- Principle of previous confirmation. Budget should be attested by parliament - Assembly of state.

The budget of European Union

The Budget of European Union is an official document for anticipation incomes and outcomes for one year. The budget is

8 Mednarodnirevizijskistandardi, mednarodnirevizijskistandardi, MRevS (International Standards of Auditing, ISA) standardi Mednarodnega združenja računovodskih strokovnjakov, ki naj bi se uveljavil na mednarodniravni v nasprotju s pravili, ki v posameznih državah urejajo tamkajšnje revidiranje računovodskih izkazov; naslednik mednarodnih smernic za revidiranje; slov.izdaja 1994

9 INTOSAI, Revizijskistandardi, Slovenski inštitut za revizijo, Ljubljana , 1994 based on distribution of income. Financial system of European union is established on the ground of member states decision of way and maximal level of incomes.

The Union has the competence to decides of outcomes considering a level of budget incomes and fundamental budget principles as follows:

- Principle of budget unitarily,

- Principle of special of time period,

- Principle of budget preliminary,

- Principle of budget unity and integrity,

- Principle of universality,

- Principle of equilibration,

- Principle of separation,

- Principle of thriftiness and economy,

- Principle of gross attestation,

- Principle of objective specialty.

\section{European Union budget proposal}

All EU institutions and agencies should according to internal procedures prepare estimations for budget draft till July the 1st. The Commission all estimations incorporate in budget proposal and submit it to Council and European Parliament till September the 1 st.

Council takes position of budget proposal including with eventual observations and propose it to European Parliament no later than October the 1st. Council keeps European Parliament informed about the reasons for acceptance own standpoint of budget proposals.

\section{The Budget procedure in Slovenia}

The comparison between budget principles in Slovenian and European Union jurisdiction shows similarities between them.

Public finance Law in Slovenia (ZJF) settles the budget procedure in four stages:

- Stage 1: preparing budget proposal - governmental function,

- Stage 2: acceptation of budget proposal - parliament function,

- Stage 3: budget execution - particular budget beneficiaries,

- Stage 4: reporting and exercise control over budget execution.

There are 212 municipalities in Slovenia. Eleven of them are city municipality and others are ordinary. With regard to budget height there is different dependence of internal audit activities.

Municipalities are financed through three sources:

- Original incomes - the main source is municipality income tax.

- State funds should be used to appropriate way.

- Municipally can statutory defined get into debt under defined conditions and restrictions:

- Debt should be a part of municipality's budget,

- It is required for municipality to acquire a conformity from Ministry for finance,

- Extension of debt should be lower than $10 \%$ annual revenues,

- Payment for principal and interest should not to exceed 5\% budget annual revenues.

Some of original sources are property tax and tax on gambling incomes, and some others. In a year 2014 there were introduced real estate tax on base of official evidence in Geodesic register (GURS) and Land register.

The purpose of Municipality budget is to finance following municipality's duties:

- Operational activities,

- Public services,

- Contributions to public services,

- Fire precautions,

- Protection against nature disaster.

In Public Finance Law (ZJF) accepted in year 1999 is budget supervision definedby a direct budget beneficiary as follows: 
"Financial supervising is a system of internal controls and internal auditing that is valid for all agencies and organizations under their competence."

Internal auditing is a subsequent financial reporting audit and efficiency, economy and effectiveness. The internal control system and internal auditing should be supplemented with reestablishing organizations of internal auditors. They are acting within the framework of direct State budget beneficiary.

Ministry competent for finance, finance supervision and budget inspection has the competences to act at following matters:

- Inspection of budget expenditures,

- Subsequent accounting and finance auditing and checking the efficiency, economy and effectiveness of common projects between different users of state budget.

- Preparative arrangements for common directions for internal auditing activities by direct state and municipality budget users. ${ }^{11}$

\subsection{The objects and subjects of public auditing and internal auditing}

The legal bases for public auditing objects are Public finance Law and Book of regulations for harmonized system of public finance internal audit activities. ${ }^{12}$

\section{The Slovenian Court of accounts}

Activities of auditors in Slovenian Court of accounts are based on the auditing standards and directed by guidelines. They were edited by International organization INTOSAI (International Organization of Supreme Audit Institutions) and INTOSAI Guidelines (European implementing guidelines for the INTOSAI auditing standards). Auditors solve some unsettled audit cases by reasonable use of IFAC Standards established (International federation of Accountants).

\section{Auditing in framework of Slovenian Ministry of finance}

Slovenian Bureau for budget supervision has the mission to perform different control activities relating expenditure of public resources. With their activities they make direct and indirect efforts forlegally, purposely and clearly use of national budget means and spending of EU budget funds. They directly control past expenditures with intention for futurepublic budget funds consumption in future should be in accordance with legitimate anticipation. With indirect activities they are included in internal control system restoration and improvement due to legal and proper public funds expenditure. Subjects of their supervising are all institutions and national and EU budget funds recipients.

Bureau their mission execute on following fields:

- Systems of internal public finance supervision, education operations for internal control activities and internal auditing trainings;

- Independent supervision of execution and consumption of European funds;

- Inspectorship of public budget;

- Directing and coordination to protect financial interests of European Union and fight against fraud.

- Bureau strives for excellence and for highest quality on their working field. They permanent work hard for achieving better working conditions and for employment adequate qualified and educated personnel with high ethical value.

- They try to carry international experience and knowledge in domestic environment by transferring knowledge from international supervising institutions.

- They work researches in domestic and international surrounding. ${ }^{13}$

$11 \mathrm{http}: / /$ www.unp.gov.si/si/

12 (Ur. list RS, št. 72/02) (http://www.uradni-list.si/1/ulonline. jsp? urlid $=200272 \&$ dhid $=43594$ )

13 Urad RS za nadzor proračuna je organ v sestavi Ministrstva za finance
Bureau for budget supervision is organized as a central agency for harmonization and coordination of internal supervision in public sector.

Bureau is an independent agency for EU funds finance control and gives accreditation, certifiesand verifies attestation of regularity. It is also a point of coordination with Europeancommission for fight against fraud- OLAF and coordinates activities in a field of financial interest of EU and reports irregularity. Important part of its activities is budget inspection.

\section{Agency for agriculture markets and county development}

Agency for agriculture markets and county development (AKTRS) was established by Slovenian government in a year 1999 with intention to execute programs SAPARD. They got an accreditation for EKUJS payment funds. They got in 2004 an accreditation as a payment agency ${ }^{14}$, after establishing internal audit function. (SNR).

Auditing and internal auditing activities were introduced in Slovenian business praxis less than twenty years ago so they are from the science point of view determined as a young knowledge. Internal auditing in public sector performs internal auditors. They should possess a title the public internal auditor or certified public internal auditor. A title can acquire an experienced person with university degree and who performed an exam for the public internal auditor or certified public internal auditor. ${ }^{15}$.

Internal auditor should not practice any executive duty neither have any direct responsibility for audited activities. It should act professionally according to Codex of internal auditing principles and professional ethics as well as standards of professional care in internal auditing.

\section{The Slovenian Institute of auditors}

The Slovenian Institute of auditors is a member of different international associations International Federation of Accountants, Federation des Experts Comptables Europeens, (FEE) and organized in different branches. Between them is presented an internal auditors section.

In business environment the duties of internal auditors means »the key to operational excellency«. Their job is examination of processes, activities and achieved business objects and consulting to management for continual improvement. They are researchers, reporters and analytics. Their activities are guidance to future activities, changing procedure in current diligence and preparing for new activities due to changing circumstances.

»Internal auditors prepare recommendations for improvement of orientations, procedures and processes in all cases where necessity is shown. Internal auditors bring basic conceptions for solving urgent troubles in business activities. Their aim is searching for the best solutions on the basis of perpetual supplementing their skills and consistent preservation their integrity proposed solutions. ${ }^{16}$

Internal audit section by Institute for auditing connects internal auditing profession on national level ant takes care for internal auditing promotion and their education on national legal basis. Members of internal audit section are auditors, who attended education organized by Institute and acquired professional tittle certified internal auditor.

Sectional work involves cooperation with the international internal auditors association The Institute of Internal Auditors,

14 Uredba za pridobitev akreditacije plačilne agencije za izplačevanje sredstev JamstvenegaoddelkaEvropskegakmetijskegausmerjevalnega in jamstvenega sklada (Ur. list RS, št. 81/03) http://www. uradniist.si/1/ulonline.jsp?urlid=200381\&dhid=64302)

15 Pravna podlaga za postopek izdajanja potrdil za naziva državni notranjirevizor in preizkušeni državni notranji revizor sta Zakon o javnih financah (100. a člen) in Pravilnik o izdajanju potrdil za naziv državni notranji revizor in preizkušeni državni notranji revizor (Uradni list RS, št. 83/2007)

16 http://www.si-revizija.si/iia/ 
(IIA) which joins over 80.000 internal auditors from 120 states. Such association is due to international acquisitionsand mergers on international level, global operations, electron trading and other high technologic achievements with direct impact to daily activities almost abusiness pressure.

\section{The Agency for Public Oversight of Auditing}

The Auditing Act (ZRev-2), that entered into force July 15th 2008, was an important stepping stone in the field of auditing in Slovenia. ZRev-2 helped formally establish the Agency for Public Oversight of Auditing that became operations on March 1st 2009. The director of Agency made a following declaration ${ }^{17}$ :

"System for public supervision over the quality of the work of auditing companies and certified auditors is extremely important since the trust and respectability of the auditing profession had to be restored due to a number of larger accounting scandals that occurred in the internationally in the past. Public oversight of the auditing quality is meant to be the institute that would help investors, shareholders, creditors and other interested groups rely on the audited accounting statements. Priority commitments of the Agency are to operate for the benefit of the public, to conduct quality public supervision over auditing, to observe transparency of operations and to respect the moral and ethical values with the purpose of becoming an efficient supervisor of the auditing profession".

\section{CONCLUSION}

In this working paper I have performed the previous achievements on a field of IMF Report forquality corporate financial reporting. The strongly recommendation wereconsiderate by establishing Slovenian Institute of auditors with its sections for accounting, auditing, internal auditing, validation, taxation, auditing IS andAgency for Public Oversight of Auditing.

\section{REFERENCES}

Beale, Ian, Roy H Bradford, Managing the Internal Audit, Kogan Page Limited, London, 1993

Borak, Neven, Spočetje ekonomske samostojnosti, Ljubljana: Znanstveno in publicistično središče, 1992

Boyton, William C, Johnson, Raymond N., Modern Auditing, John Willis \& Sons, Inc. , Hoboken, 2006

Božinovska-Lazarevska, Zorica, Transparency Reports as a Red Flag for Quality Control of Audit Firms, Journal of Modern Accounting and Auditing, David Publishing Company, El Monte, January 2013, Vol. 9, No 1, 76-93

Braiotta, Louis, Richard S. Hickok, John C. Biegler, The Audit Committee Handbooh, John Willey \& Sons, Inc., New York, 1999

Braiotta, Louis, Trent Gazzaway, Robert Colson, Sridadhar Ramamoorti , The Audit Committee Handbooh, John Willey \& Sons, Inc., Hoboken New Jersey, 2010

Buttery, Roger, Robert K. Simpson, Audit in the public sector, Woodhead-Faulkner, New York, 1990

Chambers, Andrew, Tolley 's Internal Auditor's Handbook, LexisNexis Butterworths, London, 2005,
Chambers, Andrew, Selim G.M., Vinten, Gerald, Internal Auditing, Pitman publishing, London, 1994

Cvikl, Milan M., Petra Zemljič, Zakon o javnih financah (ZJF) s komentarjem, Bonex založba, Ljubljana , 2000

Bogomir Ferfila, et al., Ekonomika javnega sektorja, Ljubljana: Fakulteta za družbene vede, 2011

Friedman, Daniel, Daniel McNeil, Morals and markets: the dangerous balance, Palgrave Macmillan, New York, 2013

Gleeson-White, Jane, Double entry : how the merchants of Venice created modern finance, W.W. Norton\& Company, Inc., New York, 2011

Goldman, Alvin L., Labor and Employment Law in the United States, Kluwer Law International, Den Haag, 1996

Horvat, Etelka Korpič, et al., Nova zakonska ureditev in poslovanje javnih zavodov, Maribor, Inštitut za lokalno samoupravo in javna naročila, 2004

Kamnar, Helena, Neven Borak, Fiskalna pravila, Ljubljana: Zveza ekonomistov Slovenije, 2013

Kavčič, Slavka, Računovodstvo za odločanje, Celje, Založba FKPV, 2011

Koletnik, Franc, Iztok Kolar, Forenzično računovodstvo, Ljubljana: Zveza računovodij, finančnikov in revizorjev Slovenije, 2008

Koletnik Franc, Notranje revidiranje, Ljubljana: Slovenski inštitut za revizijo, 2007

Koželj, Stanko, Tatjana Dolinšek, Poslovno računovodstvo, Celje, Založba FKPV, 2012

Mills, David, Quality Auditing, Chapman \& Hall, London, 1993

Mongiello, Marco, International Financial Reporting, Bookboon.com, 2010

Moussis, Nicolas, Evropska unija - pravo, ekonomija, politike, Ljubljana, Littera picta, 1999

Pogodba o Ustavi za Evropo, Luxembourg: Urad za uradne publikacije Evropskih skupnosti, 2005

Schemmann, Michael, External and Internal Auditing: The International Standards, Createspace, 2010

Stango, Antonio, et al., International economic co-operation in the central European initiative states, Trieste: IDLI- International Development Law Institute, 1997

Šinkovec, Janez, Evropsko pravo, Ljubljana : Uradni list Republike Slovenije, 1996

Tičar, Bojan, Iztok Rakar, Pravo javnega sektorja, Maribor: Inštitut za lokalno samoupravo in javna naročila, 2011

Turk, Ivan, Razvoj dojemanja ekonomskih in finančnih kategorij poslovanja v Sloveniji, Ljubljana: Zveza ekonomistov Slovenije, 2012

Zajc, Katarina, et al, Ekonomska analiza prava, Ljubljana: Uradni list R. Slovenije, 2009

Wood, Franck, David Horner, Business accounting basic, Pearson Education Limited, Harlow, 2010

Wieacker, Franz, A History of Private Law, Clarendon Press Oxford, Reprint 2003

Reference book:

IPPF - Practice Guide; Internal Auditing and Fraud, The International Professional Practices Framework (IPPF) outlines the following International Standards for the Professional Practice of Internal Auditing pertaining fraud, The Institute of Internal Auditors, December 2009

Web pages:

REPORT ON THE OBSERVANCE OF STANDARDS AND CODES (ROSC) - Republic of Serbia ACCOUNTINGAND AUDITING June 24, 2005 http://www.worldbank.org/ifa/rosc_aa_serb_eng.pdf

\section{PRIJEDLOZI ZA POŠTOVANJE STANDARDA I PROPISA NA PODRUČJU RAČUNOVODSTVA I REVIZIJE NA OSNOVU IZVEŠTAJA IMF - STANJE REPUBLIKA SLOVENIJA}

Božidar Jager, doktorand, Law Faculty of University of Maribor

Društvo ekonomistov Celje, Lava 7, SI 3000 CELJE, Slovenia

\begin{abstract}
Apstrakt:
Preporuke u Izveštaju IMF pokazuju smer politike u svrhi postizanja većeg kvaliteta poslovnih finansijskih izveštaja u određenoj zemlji. Izvještaj preporučuje uspostavljenje šireg Nacionalnog Nadzornog Komiteta za reformisanje računovodstva i reviziju, koji treba obezbediti na temelju vođenja politike, regulacije i odstalih subjekata u svrhi uvedbe prijedloga u praksu. Na temelju uspešnog iskustva ostalih zemalja se preporučuje državna strategija i Državni akcioni plan za dostizanje kvalitetnog i primernog poslovno financijskog izveštavanja.
\end{abstract}

\section{Ključne reči:}

Korporativni finansijski izveštaji, Međunarodni standardi finansijskog izveštavanja, Međunarodni standardi revizije, sistemski rizik, poređenja. 